\title{
The Role of Isolation of the Patients on Hospital Admission for Prevention of Nosocomial Infections
} \author{
Önder Ergönü|' [D \\ 1 Koç University-Işbank Research Center for Infectious Diseases, İstanbul, Turkey \\ 2 Infection Control, American Hospital, Istanbul, Turkey \\ 3 Koç University School of Medicine, Istanbul, Turkey \\ 4 Department of Microbiology, American Hospital, Istanbul, Turkey
}

Şiran Keske ${ }^{1}$ (D), Bahar Madran² (D), Aslı Yerlikaya ${ }^{3}$ (D), Gözde Akbaba² (D), Ebru Dönmez² (D), Yeşim Beşli ${ }^{4}$ (D),

\begin{abstract}
Objective: Contact precautions (CP) for the prevention of multidrug-resistant organisms (MDROs) in endemic countries is a critical element of infection control (IC) practices. In this study, we assessed the effectiveness of empiric CP on admission to the hospital in an MDRO endemic region.

Methods: The study was carried out in a 300-bed private hospital from January 2016 to September 2018. The CP indications on the day of hospital admission were decided based on determining risk factors such as long term care patients (Group 1), patients with catheters and/or interventions (Group 2), transferred from another hospital (Group 3), patients with known colonisation with MDRO (Group 4), patients with other risk factors (Group 5).

Results: In total, 539 consequent patients were observed. The mean age was 63.4 years, and $57 \%$ of the patients were male. Most of the patients were from Turkey (94\%); however, the rest were mainly from Middle-Eastern and North-African countries. Among 101 out of $539(18.7 \%)$ patients, at least one pathogen was grown, and among 73 out of 539 patients $(13.5 \%), \mathrm{CP}$ requiring pathogen was isolated. The $\mathrm{CP}$ requiring pathogens were detected in group $2(24 \%)$, group $1(19.4 \%)$ and group $3(13 \%)$. The most common pathogens were ESBLproducing Enterobacterales (5.8\%), carbapenemase-producing Enterobacterales (3.9\%), Pseudomonas spp. (3.53\%), Acinetobacter spp. (2.97\%), vancomycin-resistant enterococci (2.6\%) and methicillin-resistant Staphylococcus (1.86\%).

Conclusion: Risk assessment-based isolation precautions from the day of hospitalisation in an MDRO endemic country were found to be important among high-risk patients such as patients with catheters and/or interventions, long-term care patients and patients transferred from another medical centre. Implementation of risk-based CP than the culture-based IC strategies might be an effective approach in an MDRO endemic region while pending culture results.
\end{abstract}

Keywords: Antibiotic resistance, contact precaution, multidrug-resistant

\section{INTRODUCTION}

$\mathrm{H}$ ealthcare-associated infections (HAI) is an increasing global problem all over the world. Multidrug-resistant (MDR) pathogens, including carbapenem-resistant Gram-negative Enterobacterales, Pseudomonas spp. and Acinetobacter spp.
Corresponding Author:

Şiran Keske

E-mail:

sirankeske@yahoo.com

Received: April 6, 2021

Accepted: April 25, 2021

Published: April 30, 2021

\section{Suggested citation:}

Keske Ş, Madran B, Yerlikaya A, Akbaba G, Dönmez E, Beşli Y, et al. The Role of Isolation of the Patients on Hospital Admission for Prevention of Nosocomial Infections. Infect Dis Clin Microbiol 2021; 1: 8-13.

DOI: 10.36519/idcm.2021.35 
have become common causes of HAI, such as central line-associated bloodstream infections (BSIs), catheter-associated urinary tract infections (UTIs), surgical site infections (SSIs) and ventilatory associated pneumonia (VAPs)(1-2). These infections increase not only mortality but also healthcare $\cos t s(3)$.

The limited options for treating MDR pathogens increase the impact of infection control practices in acute care hospitals. Contact precautions (CP) is the main element for preventing MDR pathogens in endemic countries; in addition to hand hygiene and environmental cleaning, the CDC recommends it in the presence of certain multidrug-resistant organisms (MDRO) $(4,5)$. However, indication and the appropriate time for implementation of CP is critical. Culture-based CP is the general approach in hospital settings, and $\mathrm{CP}$ was administered after isolation of MDRO in the cultures. In this study, we aimed to evaluate the effectiveness of empiric CP on admission based on the risk factors for MDRO carriage in a hospital in a highly endemic country.

\section{MATERIALS AND METHODS}

\section{Study Design and Population}

This study was carried out in a 300 -bed private hospital. We collected the data from January 2016 to September 2018. Our hospital is a unique one with a very low rate of HAI with a dedicated infection control team (6). The infection control committee consists of more than thirty members and

\section{HIGHLIGHTS}

- Contact precaution requiring pathogen was detected in $13.5 \%$ of the study group.

- The multidrug-resistant microorganisms were most commonly detected among the patients to whom catheters and/or interventions implemented before hospitalisation.

- The most commonly isolated multidrug-resistant microorganisms were ESBL-producing Enterobacterales (5.8\%), carbapenemase-producing Enterobacterales (3.9\%), and Pseudomonas (3.53\%). gathering each month to manage infection control measures.

In our hospital, we administer CP to patients with defined risk factors on admission. The nurses decided the CP indications on the day of hospital admission based on the indications described in the hospital isolation precaution document. Then the infection control nurses are called, and if the patients belong to at least one of the group defined below, implementation of CP starts on the first day of hospitalisation.

\section{Group 1 includes long term care patients}

Group 2 includes patients with catheters and/ or interventions (urinary catheter, central catheter, tracheostomy, gastrostomy) implemented before hospitalisation.

Group 3 consists of the patients transferred from another hospital

Group 4 includes patients with known colonisation of MDR organisms within the last year

Group 5 consists of patients with other risk factors such as patients with neutropenia, sepsis, hemodialysis, history of surgery within the last three months, defined viral respiratory infection

The patients who belonged any of the risk groups defined above and hospitalised for at least one day were included in this study. The relevant cultures based on the patient's clinical status were taken within the 48 hours of hospitalisation; however, routine surveillance cultures were not taken.

If there was no known colonisation with MDR pathogen, or if no pathogen requiring $\mathrm{CP}$ in initial days of hospitalisation was grown, or no symptom/sign of infection, the CP was ceased on the 7th-day hospitalisation. If there was a history of known colonisation with MDR pathogens, CP was maintained during the hospitalisation despite $\mathrm{CP}$ requiring pathogens did not grow in the cultures. 
Table 1. Demographic features of the risk group for requiring contact precaution.

\begin{tabular}{|c|c|c|c|c|c|c|}
\hline & $\begin{array}{l}\text { Group } 1 \\
\mathrm{~N}=36(\%)\end{array}$ & $\begin{array}{l}\text { Group } 2 \\
\mathrm{~N}=29(\%)\end{array}$ & $\begin{array}{c}\text { Group } 3 \\
\mathrm{~N}=411(\%)\end{array}$ & $\begin{array}{l}\text { Group } 4 \\
\mathrm{~N}=4(\%)\end{array}$ & $\begin{array}{l}\text { Group } 5 \\
\mathrm{~N}=77(\%)\end{array}$ & $\begin{array}{c}\text { Total } \\
\mathrm{N}=529(\%)\end{array}$ \\
\hline Male gender & $18(50)$ & $20(69)$ & $239(58)$ & $2(50)$ & $41(53)$ & $309(57)$ \\
\hline Age (years) & $82.4(\mathrm{SD}=9.7)$ & $70.1(\mathrm{SD}=17.6)$ & $61.2(\mathrm{SD}=20.9)$ & $53.8(\mathrm{SD}=24.6)$ & $67.4 \quad(S D=20)$ & $63.4(\mathrm{SD}=20.7)$ \\
\hline Comorbidity & $34(94.4)$ & $24(82.8)$ & $270(65.7)$ & $3(75)$ & 65 (84.4) & $373(70.1)$ \\
\hline History of surgery & $25(69.4)$ & 26 (89.7) & $267(65)$ & $3(75)$ & $57(74)$ & $358(67.4)$ \\
\hline $\begin{array}{l}\text { Duration of } \\
\text { hospitalisation (days) } \\
\text { (mean) }\end{array}$ & $11.2(\mathrm{SD}=22.2)$ & $9.3(\mathrm{SD}=8.9)$ & $10.6(\mathrm{SD}=21.3)$ & $10.8(\mathrm{SD}=8.5)$ & $10.1(\mathrm{SD}=11.1)$ & $\begin{array}{c}10.4 \\
(\mathrm{SD}=19.95)\end{array}$ \\
\hline $\begin{array}{l}\text { Detection of } \mathrm{CP} \\
\text { requiring pathogen }\end{array}$ & $7(19.4)$ & $7(24.1)$ & $53(12.9)$ & $1(25)$ & $11(14.3)$ & $73(13.5)$ \\
\hline \multicolumn{7}{|l|}{ Bacterial agents } \\
\hline $\begin{array}{l}\text { ESBL }(+) \\
\text { Enterobacterales }\end{array}$ & 4 & 2 & 23 & 1 & 5 & 35 \\
\hline $\begin{array}{l}\text { Carbapenamase }(+) \\
\text { Enterobacterales }\end{array}$ & 1 & 1 & 17 & - & 3 & 22 \\
\hline Pseudomonas spp & 2 & 5 & 11 & - & 4 & 22 \\
\hline Acinetobacter spp. & 1 & 1 & 14 & - & 1 & 17 \\
\hline $\begin{array}{l}\text { Methicillin-resistant } \\
\text { S.aureus }\end{array}$ & - & - & 4 & - & - & 4 \\
\hline $\begin{array}{l}\text { Methicillin-resistant } \\
\text { coagulase-negative } \\
\text { staphylococci }\end{array}$ & 1 & - & 5 & - & - & 6 \\
\hline $\begin{array}{l}\text { Vancomycin-resistant } \\
\text { enterococci }\end{array}$ & - & - & 13 & - & 1 & 14 \\
\hline C. difficile & - & - & 2 & - & - & 2 \\
\hline
\end{tabular}

Table 2. Surgical site infections and pathogen distribution

\begin{tabular}{|l|c|c|c|c|c|c|}
\hline \multirow{2}{*}{} & \multicolumn{3}{|c|}{ Univariate analysis } & \multicolumn{3}{c|}{ Multivariate analysis } \\
\cline { 2 - 7 } & Odds ratio & $95 \% \mathrm{Cl}$ & $\mathrm{P}$ & Odds ratio & $95 \% \mathrm{Cl}$ & $\mathrm{P}$ \\
\hline Age>60 & 1.66 & $0.97-2.85$ & 0.06 & 1.72 & $1.00-2.99$ & 0.05 \\
\hline Male gender & 1.08 & $0.65-1.78$ & 0.77 & 1.07 & $0.65-1.78$ & 0.78 \\
\hline $\begin{array}{l}\text { History of surgery in the } \\
\text { last 3 months }\end{array}$ & 0.89 & $0.53-1.51$ & 0.68 & 0.84 & $0.48-1.47$ & 0.54 \\
\hline Cancer & 0.91 & $0.52-1.59$ & 0.74 & 0.92 & $0.51-1.66$ & 0.77 \\
\hline
\end{tabular}




\section{Definitions}

The healthcare-associated infections were defined according to the CDC guidelines used at the time of the study.

Pathogens requiring CP were specified based on "2007 CDC guideline for Isolation precautions", which was updated in July 2019 (4). The infection or colonisation with MDR Gram-negative bacteria, MRSA, other methicillin-resistant Staphylococci, VRE, VISA, ESBL positive bacteria are described as the main pathogens CP should be implemented.

The CP aim to prevent the transmission of epidemiologically important pathogens such as MDR Gram-negative bacteria, VRE, MRSA, C. difficile. A gown and gloves should be worn for all interventions that require interaction with the patient or patient's potentially contaminated environment.

\section{Identification and susceptibility testing of bac- terial isolates}

Standard laboratory methods and VITEK ${ }^{\circledR}$ MS system (bioMérieux) that uses Matrix-Assisted Laser Desorption Ionization Time-of-Flight (MALDI-TOF) were used for the identification of bacterial isolates. The antimicrobial susceptibility testing of the isolates was performed by using VITEK2 ${ }^{\circledR}$ AST P640 cards for Enterococcus spp., VITEK2 ${ }^{\circledR}$ AST P641 card for Staphylococcus spp., VITEK2 ${ }^{\circledR}$ AST P325 and VITEK2 ${ }^{\circledR}$ AST P327 cards for Enterobacterales, VITEK2 ${ }^{\circledR}$ AST P326 card for non-fermentative Gram-negative isolates in accordance with the manufacturer's instructions. Antimicrobial susceptibility test results were interpreted based on the European Committee on Antimicrobial Susceptibility Testing (EUCAST) recommendations.

\section{Statistical analysis}

The Student's t-test was used for continuous variables, and the Chi-square test was used for the categorical variables. In multivariate analysis, for the predictors of detection of $\mathrm{CP}$ requiring pathogen, age, male gender, known colonisation with resistant bacteria, history of surgery within the last three months and cancer were included in the model. The logistic regression with backward selection was performed. STATA (USA, version 14) was used, and the statistical significance was defined as $<0.05$.
The Institutional Review Board of Koç University approved the study.

\section{RESULTS}

In total, 539 consecutive patients were included in the analysis. The mean age of the population was 63.4 years, and $57 \%$ of the patients were male. Most of the cases belong to 2016 (52.9\%), followed by 2017 (27.5\%) and 2018 (19.6\%). The mean duration of hospitalisation was 10.4 days (1-365 days). Sixty-seven per cent of the patients had a history of surgery within the last three months. The underlying chronic diseases were observed among 373 (70.1\%) patients. One hundred eighty-six patients had hypertension, 149 patients had cancer, 104 patients had DM, 37 patients had cerebrovascular disease, 35 patients had chronic kidney disease, and 28 patients had haematological cancer. Most of the patients were from Turkey (94\%); however, the rest were mainly from Middle-Eastern and North-African countries with the highest rate of Libya and Iraq.

Most of the patients were in group 3 with 411 patients (76.25), followed by 36 patients (6.7\%) in group 1 and 29 patients (5.4\%) in group 2. The oldest patients were in group 1 with a mean of 82.4 years. The rate of chronic diseases was also most commonly among group 1 patients. The duration of hospitalisation ranges between 9.3 and 11.2 days. The most CP requiring pathogens were detected in group 2 (24\%), group 1 (19.4\%) and group 3 (13\%), respectively (Table 1 ).

Among 101 out of 539 (18.7\%) patients, at least one pathogen was detected within 48 hours of hospitalisation, and among 73 out of 539 patients (13.5\%), CP requiring pathogen was isolated. The most commonly detected $\mathrm{CP}$ requiring pathogens were ESBL-producing Enterobacterales (5.8\%), carbapenemase-producing Gram-negative bacteria (3.9\%), Pseudomonas sp. (3.53\%), Acinetobacter spp. (2.97\%), vancomycin-resistant Enterococcus (2.6\%) spp. and methicillin-resistant Staphylococcus spp. $(1.86 \%)$. In multivariate analysis, being older than 60 years was a significant risk factor for isolation of CP requiring pathogen (OR: 1.72, 95\% CI: $1.00-$ 2.99), $\mathrm{p}=0.05$, Table 2). 


\section{DISCUSSION}

Antimicrobial resistance is increasing all over the world, with high mortality and morbidity $(7,9)$. Strict adherence to infection control measures is critical for the prevention of MDR pathogen in high endemic countries. In this study, we evaluated the significance of empiric CP on admission to the hospital among patients with defined risk factors. We found that among $13.5 \%$ of 529 patients whose CP was administered, at least one MDR pathogen that required strict IC measures was isolated. The patients whom catheters and/or interventions (urinary catheter, central catheter, tracheostomy, gastrostomy) implemented before hospitalisation had the highest rate of MDR bacteria. Long term care patients also had a high rate of MDR pathogen that required implementation of $C P$. Being older than 60 years old was a risk factor for detecting $\mathrm{CP}$ requiring pathogen on admission.

The invasive interventions, including catheter insertion, urinary catheter implementation, tracheostomy before hospitalisation, were also accepted as high-risk factors for the acquisition of MDROs. Empiric CP was implemented to these patients on admission, and based on the initial cultures, this group had the highest risk for MDROs that require CP. Long-term care facilities are one of the high-risk centres for acquiring MDROs because of hosting a relatively older population with comorbidities, the patients with exposure to invasive procedures and the patients with recurrent hospitalisation $(10,11)$. In our study, group 1 represents the long-term care patients and pathogens that required CP was grown in one-fifth of these patients. Transferring a patient from another hospital is defined as another risk factor for transmission of MDROs in a high endemic country. We implemented empiric CP to these group, and MDROs were grown among 13\% of patients in initial cultures. These three groups should be handled meticulously while being admitted to the hospital because of including high patient rate with MDROs. Implementing empiric CP to these patients seems critical for the transmission of MDROs to other patients while pending initial culture results.

Our study has three years of data with high sample size. Each patient was followed up very closely by the same dedicated infection control team members. Besides these strengths, our study has some limitations. Group 4 that includes patients with known colonisation with MDR pathogen has a very low number of patients; however, this group was expected to include more patients. Information technology tasks might be more efficient not to miss these group.

In conclusion, isolation precautions from the first day of hospitalisation in an MDRO endemic country are important among high-risk patients such as patients with catheters and/or interventions, long term care patients and patients transferred from another medical centre. Patients older than 60 years old have a higher risk for MDRO carriage. Implementation of risk-based CP than the culture-based IC strategies might be an effective approach in an MDRO endemic region while pending culture results.
Informed Consent: Written consent was obtained from the patients.

Ethical Approval: Koç University Ethical Committee for Research Studies approved the study with the decision number of 2021.229. IRB1.077.

Peer-review: Externally peer-reviewed

Author Contributions: Concept - Ş.K., B.M., Ö.E.; Design - Ş.K., A.Y., G.A., Y.B., Ö.E.; Supervision - Ş.K., E.D., Ö.E.; Data Collection and/or
Processing - B.M., A.Y., G.A., E.D.; Analysis and/or Interpretation Ş.K., Ö.E.; Literature Review - Ş.K., B.M., Y.B., Ö.E.; Writer - Ş.K., B.M., A.Y., Y.B., Ö.E.; Critical Reviews - Ş.K., Y.B., Ö.E.

Conflict of Interest: The authors have no conflict of interest to declare.

Financial Disclosure: The authors declared that this study has received no financial support. 


\section{REFERENCES}

1 Tacconelli E, Cataldo MA, Dancer SJ, De Angelis G, Falcone M, Frank U, et al. ESCMID guidelines for the management of the infection control measures to reduce transmission of multidrug-resistant Gram-negative bacteria in hospitalized patients. Clin Microbiol Infect 2014; 20 Suppl 1: 1-55.

2 Thaden JT, Li Y, Ruffin F, Mascarinec SA, Hill-Rorie JM, Wanda LC, et al. Increased costs associated with bloodstream infections caused by multidrug-resistant Gram-negative bacteria are due primarily to patients with hospital-acquired infections. Antimicrob Agents Chemother 2017; 61: e01709-16.

3 Nelson RE, Slayton RB, Stevens VW, Jones MM, Khader K, Rubin MA, et al. Attributable mortality of healthcare-associated infections due to multidrug-resistant Gram-negative bacteria and methicillin-resistant Staphylococcus aureus. Infect Control Hosp Epidemiol 2017; 38: 848-56.

4 Siegel JD, Rhinehart E, Jackson M, Chiarello L, the Healthcare Infection Control Practices Advisory Committee. 2007 guideline for isolation precautions: preventing transmission of infectious agents in healthcare settings. Am J Infect Control 2007; 35: S65-164.

5 Barnes SL, Morgan DJ, Harris AD, Carling PC, Thom KA. Preventing the transmission of multidrug-resistant organisms: modeling the relative importance of hand hygiene and environmental cleaning interventions. Infect Control Hosp Epidemiol 2014; 35: 1156-62.
6 Keske Ş. The significance of multidirectional studies in control of health care-associated infections. Klimik Derg 2019; 32: 190-4.

7 Theuretzbacher U. Global antimicrobial resistance in Gram-negative pathogens and clinical need. Curr Opin Microbiol 2017; 39: 106-12.

8 Aydin M, Azak E, Bilgin H, Menekse S, Asan A, Mert THE, et al. Changes in antimicrobial resistance and outcomes of health care-associated infections. Eur J Clin Microbiol Infect Dis 2021 Feb 14. doi: 10.1007/s10096-020-04140-y. [Epub ahead of print].

9 Isler B, Keske S, Aksoy M, Azap ÖK, Yilmaz M, Yavuz SŞ, et al. Antibiotic overconsumption and resistance in Turkey. Clin Microbiol Infect 2019; 25: 651-3.

10 Marchaim D, Chopra T, Bogan C, Bheemreddy S, Sengstock D, Jagarlamudi R, et al. The burden of multidrug-resistant organisms on tertiary hospitals posed by patients with recent stays in long-term acute care facilities. Am J Infect Control 2012; 40: 760-5.

11 Bonomo RA. Multiple antibiotic-resistant bacteria in longterm-care facilities: an emerging problem in the practice of infectious diseases. Clin Infect Dis 2000; 31: 1414-22. 